\section{Intersections}

Canadian Journal of Music

Revue canadienne de musique
Intersections CANADIAN JOURAL OF MUSIO

\title{
Formal Mixture in the Sonata-Form Movements of Middle- and Late-Period Beethoven
}

\section{James S. MacKay}

Volume 31, numéro 1, 2010

URI : https://id.erudit.org/iderudit/1009287ar

DOI : https://doi.org/10.7202/1009287ar

Aller au sommaire du numéro

\section{Éditeur(s)}

Canadian University Music Society / Société de musique des universités canadiennes

ISSN

1911-0146 (imprimé)

1918-512X (numérique)

Découvrir la revue

Citer cet article

MacKay, J. S. (2010). Formal Mixture in the Sonata-Form Movements of Middleand Late-Period Beethoven. Intersections, 31(1), 77-99.

https://doi.org/10.7202/1009287ar

\section{Résumé de l'article}

La modulation diatonique se définit comme la coloration locale d'une progression diatonique par l'emprunt de tons ou d'accords à la tonalité majeure ou mineure homonyme. Dans ses efforts visant l'élargissement des ressources tonales, Beethoven a fait avancer cette technique : il a emprunté des processus sonores de grande échelle de la tonalité homonyme d'une composition, technique que je qualifie de modulation formelle. Après en avoir retracé les origines à certaines oeuvres de Johann Sebastian Bach, Carl Philipp Emanuel Bach, Domenico Scarlatti et Joseph Haydn, je montre comment tout au long de sa carrière Beethoven s'est appuyé sur l'emploi de cette technique par ses prédécesseurs, élargissant et diversifiant ainsi les ressources tonales des structures sonate de la fin de l'ère classique.
All Rights Reserved (C Canadian University Music Society / Société de musique des universités canadiennes, 2012
Ce document est protégé par la loi sur le droit d'auteur. L'utilisation des services d'Érudit (y compris la reproduction) est assujettie à sa politique d'utilisation que vous pouvez consulter en ligne.

https://apropos.erudit.org/fr/usagers/politique-dutilisation/ 


\title{
FORMAL MIXTURE IN THE SONATA-FORM MOVEMENTS OF MIDDLE- AND LATE-PERIOD BEETHOVEN $^{1}$
}

\author{
James S. MacKay
}

\section{INTRODUCTION}

As Charles Rosen asserts, Ludwig van Beethoven was one of the first major composers to explore remote tonal relationships extensively in his sonata expositions (Rosen 1995, 240; 1998, 382-83). One of the means by which he did so was to borrow large-scale tonal processes from a composition's parallel key. In essence, this procedure can be seen as an example of modal mixture (defined as a local colouration of a diatonic progression by borrowing tones or chords from the parallel major or minor key) functioning at deeper levels of formal structure. For instance, although major-mode classical sonata-form expositions typically modulate to the dominant, and minor-mode expositions typically modulate to the mediant, beginning around 1800 Beethoven often reverses these procedures, writing minor-mode sonata-form expositions that modulate to the dominant, and major-mode sonata-form works that modulate to the mediant (or other third-related key).

For the purpose of this study, the technique of borrowing tonal procedures from the parallel key at a work's thematic or formal level will be termed formal mixture. ${ }^{2}$ I will trace the origin of formal mixture to certain works by J. S. Bach, Domenico Scarlatti, C. P. E. Bach, Joseph Haydn, and Wolfgang Amadeus Mozart. I will then show how Beethoven expanded upon his predecessors' use of the technique in the works of his early Viennese period (1794-99), leading ultimately to the experimental tonal plans found in his sonata-form expositions of ca. 1800-05 and beyond. Additionally, since the use of distant third-related keys in a major-mode sonata exposition has ramifications for tonal decisions later in the form, I will briefly consider how Beethoven's use of formal mixture in his expositions affects musical decisions in his recapitulations.

1 This paper is an expanded version of a presentation given at the AMS Southern Chapter meeting, Tuscaloosa, AL, February 2005. The author would like to thank this journal's anonymous reviewers and their editor Edward Jurkowski for their valuable comments on earlier drafts.

2 Thanks are due to Dr. François de Médicis (Université de Montréal) for suggesting this term to me. 
Of the two varieties of formal mixture listed above, the more common one involves transplanting the modulation to the dominant-typical of majormode works-to works in the minor mode. This type of formal mixture has a relatively long history before Beethoven: James Hepokoski and Warren Darcy comment that the tonic-to-dominant minor tonal plan "may be regarded as a second-level default [i.e., the most common alternative to the norm] with regard to key choice [for sonata expositions] ... a recognized generic option, one with deep roots in the tonal past, but one much less frequently chosen" (Hepokoski and Darcy 2006, 315). Despite its relatively infrequent use, the musical viability of this tonal plan is not surprising, since it involves substituting one closely related secondary key (the dominant minor) for another (the mediant major).

Though modulation to the mediant major is decidedly the norm in minormode sonata expositions, the tonic-dominant tonal juxtaposition at the formal level of structure was never entirely out of the question, even in the baroque period. (Of course, this modulation is commonplace in minor-mode fugal expositions, although in such a case, it comprises a prolongation at the phrase level of structure rather than at a deeper formal level.) To cite one example of this modulation in a work of moderate length, Domenico Scarlatti modulates to the dominant minor in the first part of his Sonata in C minor, Kirkpatrick 11, his preferred choice in minor-mode works (Longyear and Covington, 1988, 449). ${ }^{3}$ One can find the same tonal strategy in certain short binary-form compositions by J. S. Bach: for instance, the minor-mode Allemandes from his English suites all bypass the mediant in favour of the dominant minor. Nor is this an isolated occurrence in Bach's compositional output: two compositions from his WellTempered Clavier use this modulation at their midpoint (the fugue in D minor from Book One, and the prelude in E minor from Book Two).

Given such precedents, it is not surprising that classical composers occasionally use this tonic-to-dominant minor tonal plan in place of the normative move to the mediant major, though, to be certain, this alternative plan was more common in short forms than it was in sonata forms. Haydn, for instance, modulates to the dominant minor in the trio section of his Symphony no. 58, third movement. Since the preceding menuet alla zoppa had modulated from $\mathrm{F}$ major to its dominant, $\mathrm{C}$ major, the minore trio, by modulating from $\mathrm{F}$ minor to $\mathrm{C}$ minor, provides the listener with an attractive tonal parallelism between the two sections. Other Haydn works that incorporate this modulation include Symphony no. 29, third movement, trio; Symphony no. 37, second movement, trio; and Symphony no. 63 (La Roxelane), second movement, mm. 73-98, all

3 There is some debate as to whether Scarlatti's sonatas, in which the second half's tonal resolution typically coincides with the return of the subordinate theme rather than the main theme, truly represent what is conventionally termed sonata form (Rosen is representative of this view: "This is magnificent, of course, but it is not sonata form and none the worse for that" $[1988,136]$. Compare with James Webster's term "expanded binary form" for such works [New Grove 1981, 690]). Hepokoski and Darcy $(2006,344)$ categorize such works as a Type 2 Sonata: pages $353-87$ explain their rationale in depth. 
works in binary form. In the last example, a theme in binary form with variations, Haydn modulates from $\mathrm{C}$ minor to the mediant, E-flat major, with the theme's first two appearances, but modulates to the dominant minor for tonal variety the third time around.

This tonal strategy can also be found (albeit rarely) in minor-mode classical sonata expositions: Haydn's Farewell Symphony (no. 45 in F-sharp minor), first movement, written in 1772, provides an early example. ${ }^{4}$ Haydn first feints toward the expected mediant major (A major) following the main theme (mm. 21-23), but then continues to the dominant minor (C-sharp minor) in $\mathrm{mm}$. $47 \mathrm{ff}$., a tonality that is subsequently confirmed by a perfect authentic cadence and extended tonic pedal to end the exposition. The relentless Sturm und Drang of the movement's opening measures never provides space for a contrasting theme to develop: mm. 17-64 form what Jens Peter Larsen termed an expansion section, in which the subordinate key is confirmed by cadential gestures rather than by thematic ones, an expositional strategy common in the mid-eighteenth century (Larsen 1988)..$^{5}$ This nervous and dramatic passage is dominated by sequential progressions, permitting statements of the main theme incipit in a variety of tonal regions (some quite distant from the original key of F-sharp minor), thus guaranteeing a uniformity of mood as the exposition proceeds relentlessly to its unusual subordinate key.

As if to compensate for the arrival of this somewhat anomalous tonal goal, it is noteworthy that Haydn, having assiduously evaded A major in the exposition, states this tonal region prominently as the development begins. In this regard, Haydn might have been modeling on C. P. E. Bach, who used this tonal plan in a number of minor-mode sonata-form movements, including his Sonata in A minor, first movement, from the Württemberg set (Wq. 49/1), which Haydn could plausibly have known. It is well known that Haydn acquired C. P. E. Bach's Prussian sonatas fairly early on in the 1750 (Geiringer and Geiringer 1982, 30, among others). H. C. Robbins Landon, on the basis of documentary and stylistic evidence, logically extrapolates that Haydn must have been familiar with much more of C. P. E. Bach's works than that single set of sonatas, illustrating a striking similarity between a passage from one of the Württemberg sonatas (no. 3, in E minor) and Haydn's D major sonata, Hob. XVI: 19, as evidence of Bach's influence (Robbins Landon 1978, 337-40).

Notably, and perhaps not coincidentally, C. P. E. Bach, like Haydn, then begins the development with main theme material in the relative major. Thus Haydn seems to be paying homage to his predecessor both tonally and thematically. One could view this emphasis of the mediant major in the development as a compensatory strategy: it is as if Haydn wishes to eliminate the exposition's anomalous tonal goal from the listener's memory. C-sharp minor therefore sounds like an unexpected tonal detour rather than a true alternate tonal

4 See the detailed discussion of this movement in Webster (1991, 30-38).

5 Hepokoski and Darcy $(2006,51-64)$ categorize such expositions as one of many possible continuous exposition models. 
plan for the exposition; the rest of the movement proceeds according to the tonal norms of the classical period.

Beethoven, as well, apparently liked the uniformity of mood that this type of formal mixture could impart to a sonata exposition, as he used the tonic-todominant minor tonal plan in one of the first sonata-form movements he ever wrote-the Piano Quartet in E-flat major, WoO 36. The work's second movement is in sonata form, fast in tempo, and in the remote key of E-flat minor. Beethoven's large-scale tonal plan is striking compared to the high classical norm: he avoids the mediant major for the subordinate theme, choosing instead the dominant minor (see example 1). It is hard to pinpoint why Beethoven might have been inspired to use this novel tonal plan. It is unlikely that he knew of Haydn's precedent in the Farewell Symphony at this early stage in his career. ${ }^{6}$ Nor were there many sonata-form works in Mozart's output that might have influenced the young Beethoven in this regard. The Mozart violin sonata movement on which this work was modeled, K. 379/396 of 1781 (Kerman 1994, 220; Miller 2004, 20), moves from G minor to the diatonic mediant, B-flat major. As Kerman remarks, even in modelling upon his illustrious predecessor, Beethoven's choice of key for the subordinate theme was wilful (Kerman 1994, 220). Mozart did write minor-mode slow movements in two early string quartets (K. 168 and 171 ) that move from tonic to dominant minor,7 but it seems unlikely that these works were familiar enough in the 178 os for Beethoven to have encountered them.

Given the relative paucity of this tonal plan in Haydn and Mozart, Beethoven's decision to move to the dominant minor in place of the expected mediant major in this work may stem from older precedents, such as J. S. Bach. As noted above, Bach's Well-Tempered Clavier contains two binary-form compositions that modulate to the dominant minor at their respective midpoints (the D-minor fugue from Book 1 and the E minor prelude from Book 2). Since Beethoven had played these works frequently in his youth, ${ }^{8}$ it is reasonable to posit that he recalled this tonal plan when incorporating into this sonata exposition. Another possible influence upon Beethoven's tonal procedure may be via the keyboard music of C. P. E. Bach. For instance, an incomplete survey of Bach's keyboard sonatas reveals that he used the tonic-to-dominant minor modulation relatively frequently in his minor-mode sonata expositions, ${ }^{9}$ including once, as noted above, in the widely known Württemberg set.

6 At the time that Beethoven composed his piano quartet, the Farewell Symphony had just been published by Sieber in 1784, and had been premiered in Paris that April (Robbins Landon 1978, 181), presumably the first time the symphony had ever been heard outside of Eszterháza.

7 Hepokoski and Darcy note that this tonal plan is "rare in Mozart," stressing that these quartets are early works and (by implication) not representative of his mature procedures $(2006,315)$.

8 The fact that Beethoven performed these works during his formative years has been recounted, among other places, in Rosen $(1998,385)$.

9 Roughly one in four of C. P. E. Bach's minor-mode sonatas that were published in volumes 12 and 13 of Le Trésor des pianistes uses this modulation in its exposition. This collection is a crosssection of his best-known keyboard works, many of which circulated widely during Beethoven's time. 

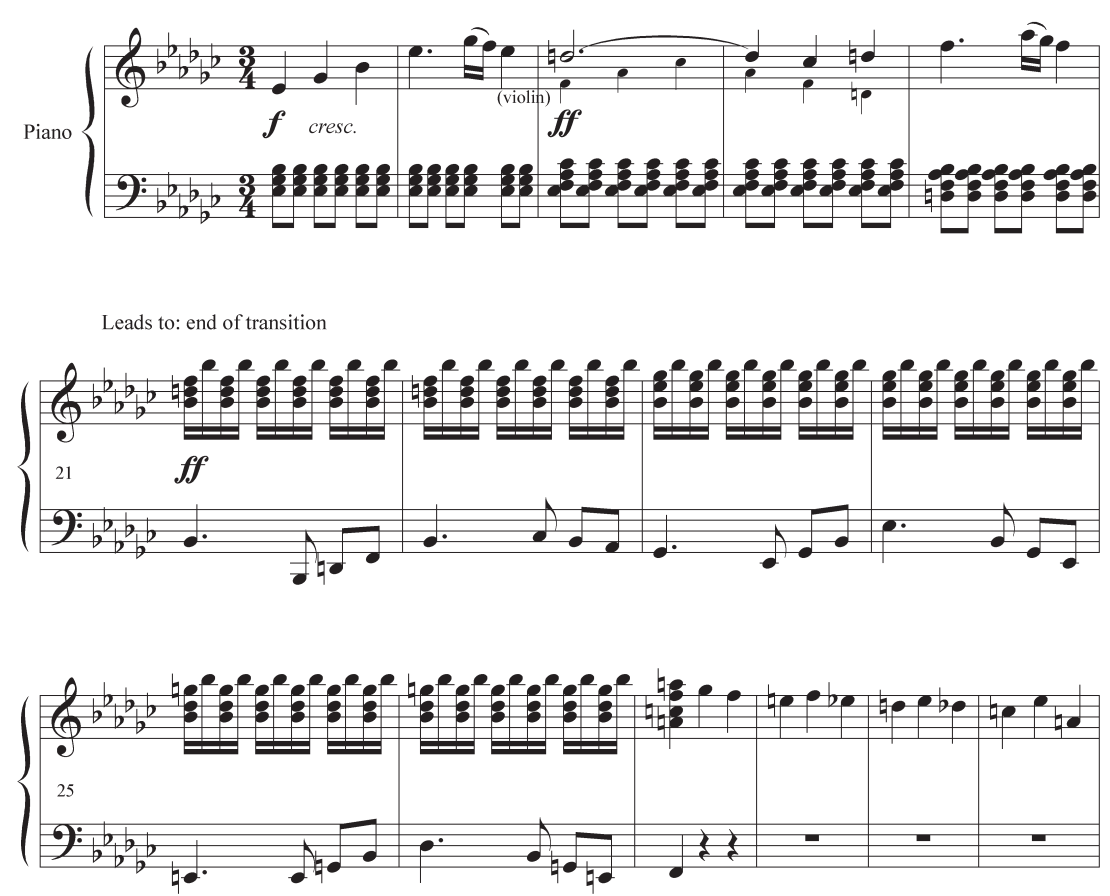

(B-flat minor: V)

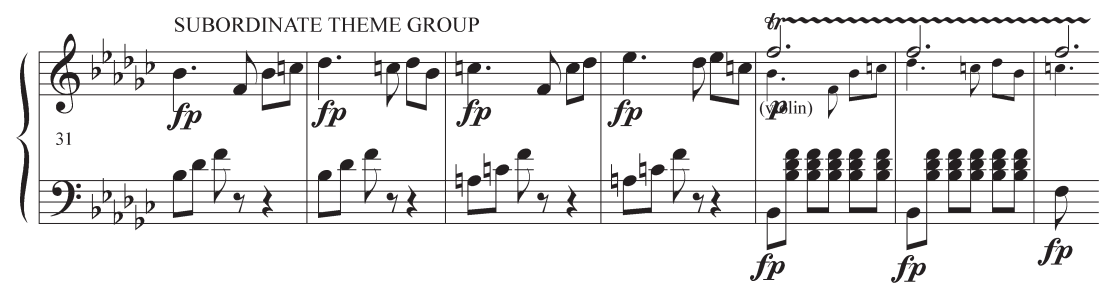

Example 1. Beethoven, Piano Quartet in E-flat major, WoO 36, second movement (piano part except where otherwise indicated): beginning of main theme (mm. 1-5) and link to subordinate theme in the dominant minor ( $\mathrm{mm} .21-37)$

These piano quartets, it has been remarked, provided Beethoven with a few thematic ideas for his op. 2 piano sonatas, completed nearly ten years later. ${ }^{10}$ Perhaps during the process of recycling these early works' thematic material, Beethoven was also inspired to revisit tonic-dominant polarity in a minormode sonata exposition. Though Beethoven modulates conventionally to the relative major in the first movement of his Sonata in F minor, op. 2, no. 1, the work's closing movement has a Sturm und Drang exposition that modulates to the dominant minor instead of the relative major. As in the opening movement of Haydn's Farewell Symphony, the expected mediant major withheld

10 See Miller $(2004,22)$, in which he notes that writers as far back as Anton Schindler and Alexander Thayer have noted Beethoven's re-use of material from these early works. 
from the exposition appears as the development begins, likely, as in Haydn (and in C. P. E. Bach) to compensate for its absence earlier in the form. Joseph Kerman notes that the Beethoven and Haydn movements resemble each other far more than superficially: along with the similarity of their expositions' tonal structure, both movements feature a lyrical melody as the centrepiece of their development sections (Kerman 1994, 221). Thus, Haydn's influence on Beethoven (to whom, moreover, he had recently given instruction in counterpoint and composition) is not untenable here.

All of the works cited above take the large-scale tonal procedures of majormode sonata expositions and utilize them in minor-mode sonata expositions. Though this tonal plan is relatively common in C. P. E. Bach's minor-mode sonata-form movements, it seems to rank as an atypical experiment in Haydn, Mozart, and early Beethoven. Haydn never used the tonal procedure of the Farewell's first movement again in a sonata-form work; Mozart's flirtation with tonic-dominant polarity in minor-mode sonata expositions was limited to a pair of early string quartets. And Beethoven, following the early experiments of his piano quartet, $\mathrm{WoO}_{36}$, and the op. 2, no. 1 finale, never used the dominant minor as subordinate key again in a sonata-form movement until after 1800; all of his other minor-mode sonata-form expositions written during this era modulate conventionally to the mediant. ${ }^{11}$

However, at the outset of the nineteenth century, Beethoven explored tonicdominant polarity in minor-mode sonata expositions systematically in multiple works. The single-mindedness of character that results from this decision is evident in the first work of this period that employs such a modulation: his Violin Sonata in A minor, op. 23, first movement. The subordinate theme, cast in the dominant minor, maintains and reinforces the fiery character of the opening, which Beethoven further continues as the development begins, with the return of opening material in the subdominant minor. Moreover, unlike op. 2, no. 1, where the tonic-to-dominant minor tonal plan was virtually unique among Beethoven's earlier sonata-form movements, this movement is the first among many from a brief five-year period in which Beethoven regularly chooses the dominant minor as subordinate key, even more frequently than he uses the customary mediant major. For instance, the finale of the Moonlight Sonata (op. 27, no. 2) and the outer movements of the Tempest Sonata (op. 31, no. 2) all modulate to this tonal region in their expositions, as does the opening movement of the Kreutzer Sonata, op. 47, and the finale of the Appassionata Sonata, op. 57.

Though the substitution of the dominant minor for the mediant major in the subordinate theme group is certainly not Beethoven's universal procedure during these years, it does occur in roughly half of the minor-mode sonataform movements that he wrote ca. 1801-05, a proportion even greater than

11 Beethoven modulates to the mediant major in the opening movements of op. 1, no. 3 ; op. 2 , no. 1 ; op. 13; op. 18, no. 4 ; and op. 49, no. 1 , as well as the opening and closing movements of op. 9, no. 3 , and op. 10, no. 1. Beethoven does at first choose the mediant minor (E-flat minor) as subordinate key in op. 13; however, the use of mixture is localized, as the requisite mediant major arrives definitively with the exposition's closing measures. 
what we find in C. P. E. Bach's keyboard works. ${ }^{12}$ This "doggedly negative tonal choice [that] produces a chillingly dark, fatalistic, punishing, or pessimistic referential layout" (Hepokoski and Darcy, 2006, 315) is something quite new in Beethoven's conception of the minor-mode sonata. Given his increasing deafness and resultant social isolation around this time, it is tempting to look for biographical reasons for this shift in conception. Whether or not Beethoven's difficult life circumstances during these years elicited from him a grim, stormy single-mindedness when he wrote in the minor mode, it is beyond question that this character is more evident in Beethoven's music from the early years of the nineteenth century than at any other time in his career.

\section{II}

As we have witnessed, in the early years of the nineteenth century (1801-05), Beethoven experimented regularly with formal mixture in minor-mode sonata expositions. At the same time, he also explored in earnest the other variety of tonal mixture-mediant relationships in major-mode sonata expositions-as well. Beethoven's reversal of conventional tonal procedures in both major- and minor-mode sonata expositions is statistically too striking to be coincidental, suggesting an interrelation between these two musical decisions. Astonishingly, Beethoven used the two types of formal mixture in ten of thirty-two sonata expositions-almost a third of the time-from 1801 to 1805 , whereas he used this technique virtually not at all (two out of nearly eighty works) up until 180o, and barely one-sixth of the time (ten of sixty works) following 1805 .

Unlike the use of the dominant minor as subordinate key in minor-mode works, the substitution of mediant relationships for the expected dominant in major-mode works can have significant deep-level tonal ramifications. The dominant-tonic polarity that typifies the classical major-mode sonata exposition, which elicits a balancing V-I motion in the movement's second half, is simply a background-level manifestation of the I-V-I progression that is the foundation of conventional common-practice tonality, a progression whose combination of common tones and stepwise voice-leading virtually guarantees tonal coherence. This tonal plan can quickly become clichéd, however; consequently, composers began to seek out different means of large-scale organization in their compositions by the beginning of the nineteenth century. Rosen $(1995,237-57)$ cites a number of examples from Haydn to Rossini illustrating the new emphasis on third-related harmonic motion. To cite one specific device whose ascendance coincided with Beethoven's active years, composers such as Haydn and Mozart began to experiment with other common-tone-related tonal regions to which they could modulate during the course of a composition, exploring the juxtaposition of third-related tonal keys

12 Interestingly, the three minor-mode sonata-form movements from this period in which Beethoven modulates to the mediant major are all in $\mathrm{C}$ minor (the outer movements of his Violin Sonata, op. 30, no. 2, and the opening movement of his Piano Concerto no. 3, op. 37), which supports Joseph Kerman's thesis that Beethoven, throughout his career, treated C minor differently from other minor keys (1994, 217-19). 
in place of the fifth-related large-scale tonal design that typified eighteenthcentury practice in major-mode works. This tonal strategy was first explored in earnest by Haydn in his operatic finales around 1780 (Robbins Landon and Jones, 1988, 211), possibly in response to the influence of Domenico Cimarosa, ${ }^{13}$ and was carried further by Beethoven in his instrumental works at the start of the nineteenth century.

Though Beethoven occasionally employed diatonic third-related tonal regions in his major-mode sonata expositions (for instance, the opening movement of his string quartet in E-flat major, op. 127, modulates from its home key to $\mathrm{G}$ minor as the subordinate theme begins in $\mathrm{m}$. 41), he was far more likely to move to a more distant third-related key (a chromatic mediant or submediant). The four most common such third-related tonal regions in major-mode works are the mediant major, flatted mediant, submediant major, and flatted submediant (i.e. III\#, bIII, VI\#, and bVI). The bVI and bIII tonal regions, when used as secondary keys, behave like the mixture chords of which they are an expansion: they act as more intense and remote substitutes for their diatonic equivalents. Moreover, bVI shares a common tone with the tonic chord, two common tones with the Italian and French augmented sixth chords, and three common tones with the German sixth chord, providing an easy entrance into, and exit from, this remote tonal region. Further, III\# and VI\#, though not literally mixture chords, but rather, diatonic triads whose qualities have been altered ("mixed") from minor to major, can function locally as applied dominants of the diatonic subdominant and supertonic regions, respectively, thus forging a tenuous link between these somewhat distant tonalities and the home key. Tonicizing any of these chromatic chords and prolonging them over a longer formal span is a logical next step in expanding the range of tonalities within a sonata exposition. Finally, the tonal ambiguity of mediants enables them to function as colouristic substitutes for the dominant as well. ${ }^{14}$

The decision to broaden tonal resources beyond the tonic-dominant axis would have ramifications for the future of the tonal system itself. As Charles Rosen states, "The relation of tonic to dominant is the foundation of Western triadic tonality. The attempt of the early nineteenth century to substitute ... mediant relationships for the classical dominant amounted to a frontal attack on the principles of tonality, as it eventually contributed to the ruin of triadic tonality. This ruin was accomplished from within the system, however, as mediant relationships were essential to tonality as conceived in the eighteenth century" $(1995,237)$.

Certainly, as Rosen goes on to suggest, mediant relationships, the norm in minor-mode compositions, were far from novel, even in major-mode sonataform works during the classical period, though they were typically withheld

13 Ethan Haimo (2011) notes that the mediant shifts in the finale of Haydn's opera La fedeltà premiata model closely the same section of Domenico Cimarosa's opera L'Infinideltà fedele.

14 This is quite different from Beethoven's localized use of a chromatic mediant in the opening movement of his Sonata in D major, op. 10, no. 3, in which the III\# in measure 22 is a stopover between the $\mathrm{B}$ minor region on which the transition is centred, and the ultimate A major of the subordinate theme group. 
until later in the form, often to begin the development, for instance. In the slow movement of Haydn's String Quartet in D major, op. 50, no. 6 (The Frog), for instance, he moves abruptly from the subordinate key (F major) as the exposition concludes, to its flatted submediant, D-flat major, at the outset of the development. Nor is this atypical for late-period Haydn: the first movement of his String Quartet in F major, op. 74, no. 2, moves from C major as the exposition concludes, to the submediant major, A major (VI\# of C major, locally; also III\# with respect to the home key). Many comparable examples can be found in Haydn's sonata-form movements written after ca. 1785, which might have impressed and influenced the young Beethoven.

Haydn on occasion transfers this tonal procedure-modulation to thirdrelated keys-to conclude the opening section of major-mode works (though never in works in sonata form), permitting the introduction of remote tonal regions at a relatively early point in the musical discourse. As an illustration of such a process, consider the rondo finale of Haydn's Sonata in E major, Hob. $\mathrm{XVI}$ : 31. The opening eight measures of this rondo move from $\mathrm{E}$ major to a unison G-sharp. This note, at first implying a half cadence in the relative minor (C-sharp minor) is recast as the tonic of G-sharp minor to begin the next section. The ambiguity of this moment allows Haydn to first hint at a remote key (could this G-sharp be the tonic of the mediant major, or perhaps the dominant of C-sharp major, the raised submediant?), and then to continue in the closely related diatonic key of G-sharp minor. ${ }^{15}$

The slow movement of Haydn's String Quartet in E-flat major, op. 71, no. 3, provides another instance of a third-related shift within the opening half of a binary form composition (see example 2). The movement begins in B-flat major and seems initially to be heading towards the dominant, with the F major triad preceded by its dominant seventh in mm. 6-7. Haydn certainly could have concluded this phrase with a cadence in the dominant (illustrated by the hypothetical re-composition in the example's third system); instead, he reinterprets this $\mathrm{F}$ major chord as III of the mediant minor (D minor) and cadences there in $\mathrm{m}$. 8. Haydn makes no attempt to introduce this mediant as if it could be the dominant of a related key (the final chord's minor quality pre-empts this possibility). Moreover, Hayd n unambiguously selects the diatonic mediant minor as subordinate key rather than the more distant mediant major (III\#).

Haydn and Mozart also incorporated tonal moves by thirds into their sonata-form expositions, while retaining the standard tonic-dominant polarity between the beginning and the end of the section. This can be accomplished in different ways: for example, mediant shifts in a transition section can create an intermediate goal between a work's tonic and dominant regions. Haydn's Piano Trio in D major, Hob. XV: 24, first movement, restates main theme material in F major (bIII) within a long transition section. This moment might have passed without notice, but Haydn precedes it with a grand rhetorical

15 As noted above, III\# can often be interpreted as the dominant of the relative minor; decades later, Beethoven would also employ this tonal procedure in the finale of his String Quartet in E-flat major (Harp), op. 74: the first part's move from E-flat major to its concluding G-major triad is clearly a modulation from the home key to the dominant of the relative minor. 

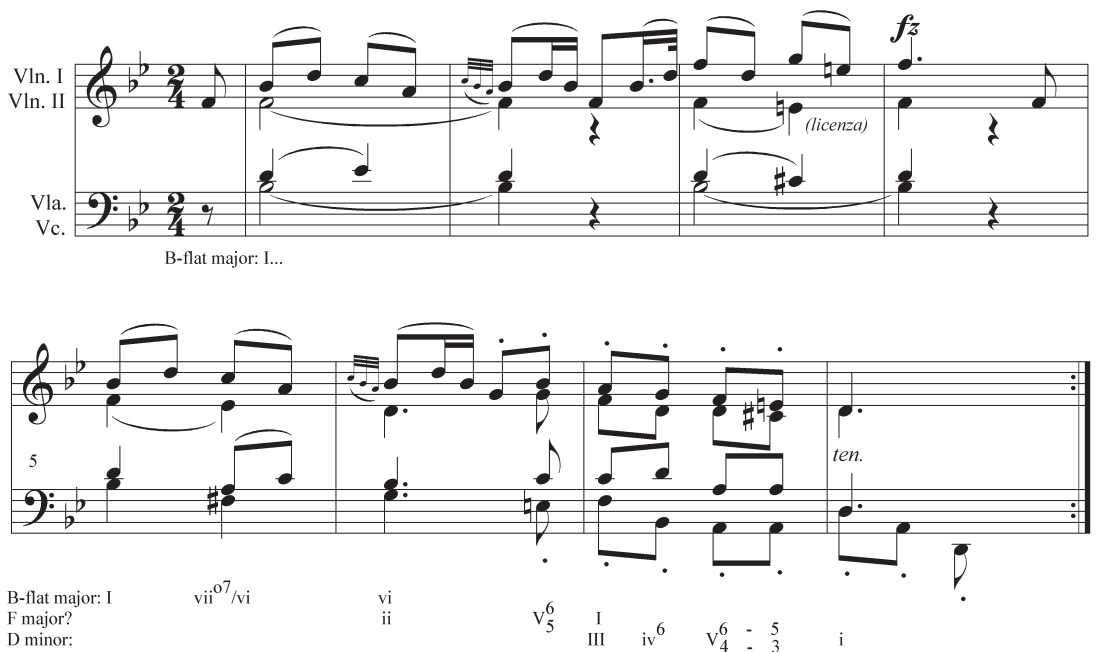

Measures 5-8: Hypothetical recomposition to end in F major

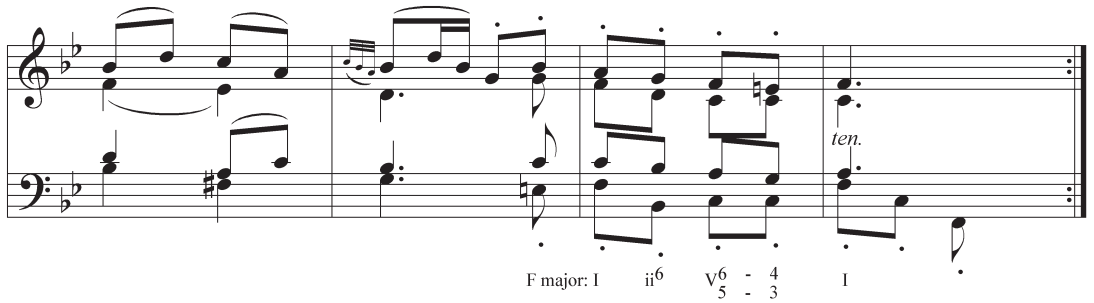

Example 2. Haydn, String Quartet in E-flat major, op. 71, no. 3, second movement, mm. 1-8 (reduction)

pause. Nevertheless, this third-related tonal region (encountered in mm. 3off.) is clearly a diversion on the route to the conventional subordinate key, A major. After this emphatic use of $\mathrm{F}$ major, a sequential repetition in $\mathrm{mm}$. 32-33 hints at $\mathrm{G}$ minor, after which both tonalities are subsumed into an extensive D minor tonal region that leads (as a modally mixed subdominant chord) to the dominant of A major, preparing the subordinate theme's arrival in $\mathrm{m} .46$.

Another strategy that permits the introduction of third-related tonal regions within a sonata exposition, one that dates back at least to Haydn and Mozart, ${ }^{16}$ is the use of tonal excursions within the subordinate theme itself. Once the subordinate key has been established, a composer can destabilize it by hinting at-or even modulating briefly to-third-related tonalities. Rosen $(1995,237-40)$ cites two examples from the piano trio literature that illustrate this technique: the opening movements of Mozart's K. 542 in E major, and Haydn's Hob. XV: 28 in the same key. ${ }^{17}$ In both instances, as Rosen illustrates,

16 See Rosen (1995, 237-40; 1998, 111-13).

17 The finale of Haydn's Trio in C major, Hob. XV: 27 , has a similar (if fleeting) excursion from $\mathrm{G}$ major to its diatonic mediant B minor midway through its subordinate theme, and the slow move- 

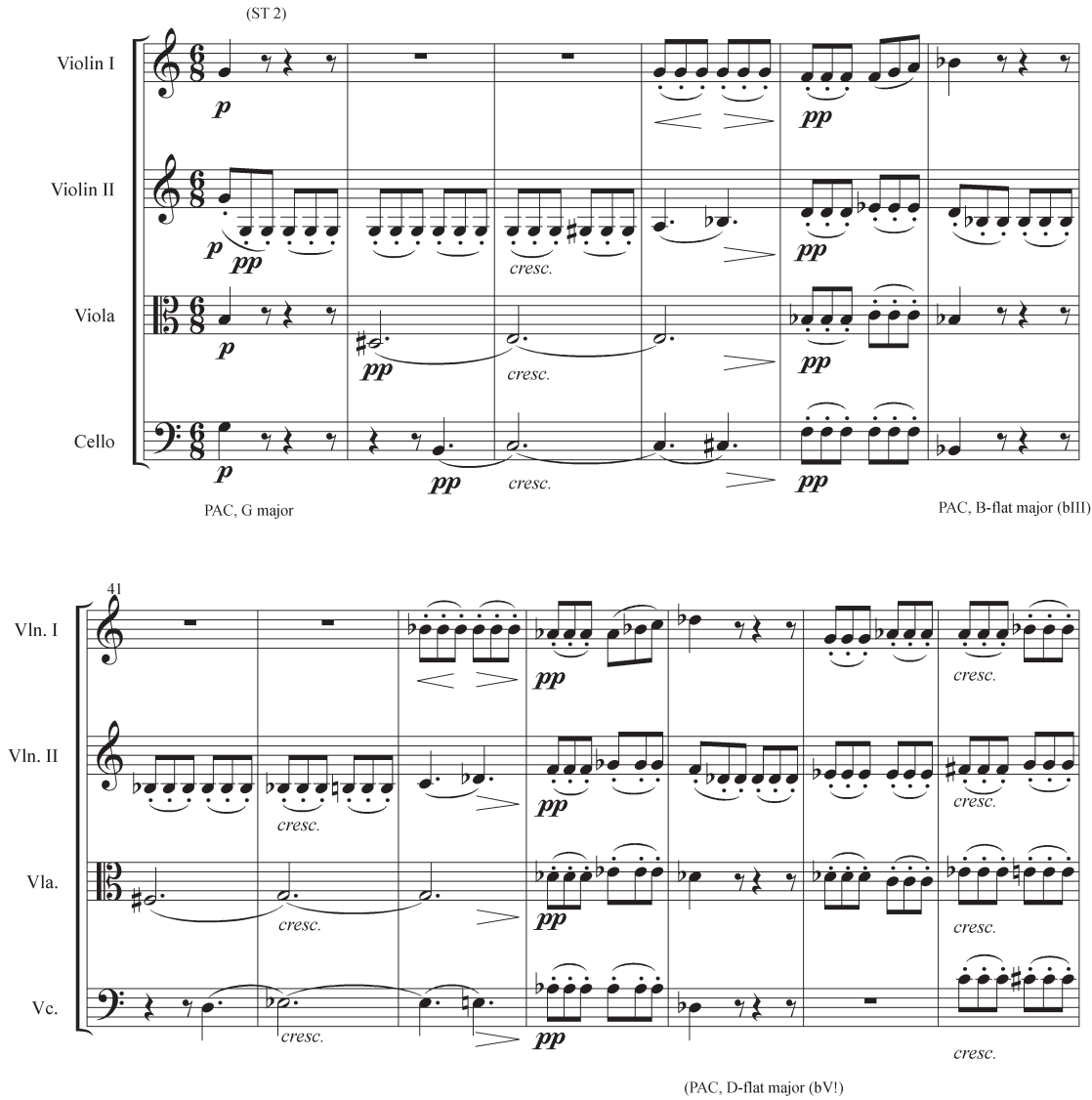

Example 3. Haydn, String Quartet in G major, op. 54, no.1, second movement, mm. 35-53: third-related tonal excursions within subordinate theme group

the exposition modulates to the customary dominant (B major) as subordinate key, then introduces this key's flatted submediant region ( $\mathrm{G}$ major) before returning to B major as the exposition concludes. The new key introduced in the subordinate theme is a chromatic mediant of the home key, E major (specifically, the relative major of the parallel minor), but is not treated as such. Because of the lengthy establishment of the dominant key prior to the appearance of G major, one cannot argue that Haydn or Mozart created a tonic-to-mediant polarity in the exposition: $\mathrm{G}$ major is merely an interesting tonal detour within the exposition's standard I-V large-scale motion. This tonal procedure directly contrasts with Beethoven's use of third-related keys for his subordinate themes in major-mode works after about 1800 , in which the mediant-related key is a stand-in for, rather than a colouristic expansion of, the traditional dominant tonality. 

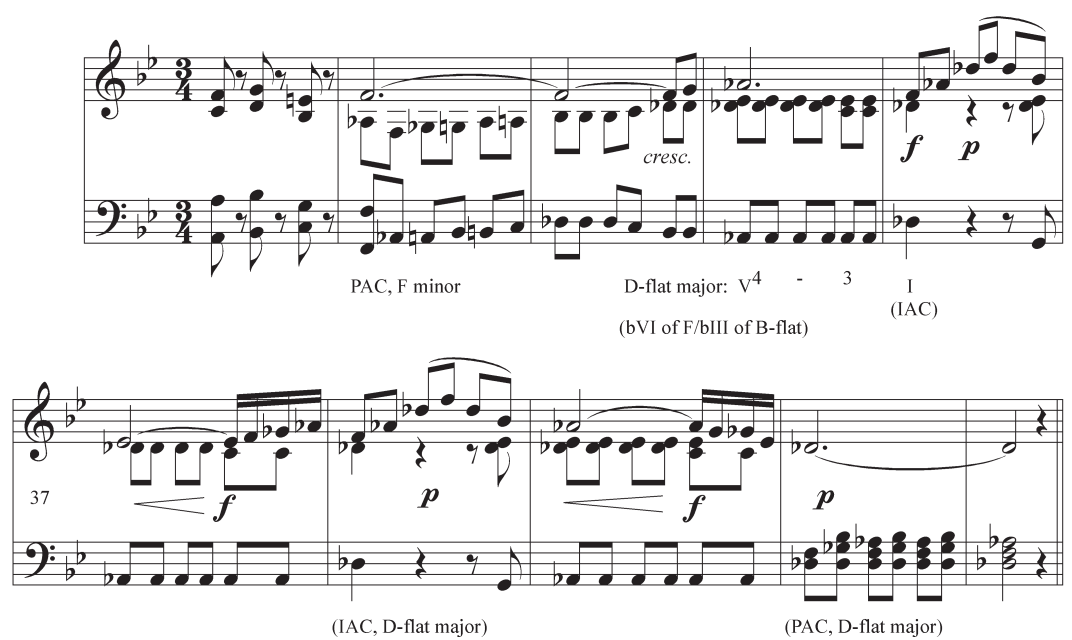

Example 4. Haydn, Seven Last Words, Sonata I, mm. 31-40 (reduction): mediant-related excursion at end of exposition

The slow movement of Haydn's String Quartet in G major, op. 54, no. 1, is a particularly remarkable example of third-related excursions within a subordinate theme. The transition's move from $\mathrm{C}$ major to its dominant in $\mathrm{mm}$. 21-26 is conventional, but once the music is firmly grounded in the subordinate key ( $\mathrm{G}$ major), Haydn moves by successive ascending minor thirds to a pair of distant tonalities (B-flat major and D-flat major), each confirmed by cadences in mm. 40 and 45, respectively (see example 3). Haydn, however, declines to take the next radical step-i.e., ending the exposition in one of these remote keys: he re-establishes $\mathrm{G}$ major in $\mathrm{m}$. 48, with nearly five measures of an emphatic cadential six-four confirming this return.

Another of Haydn's works from the mid-1780s-Sonata I from his Seven Last Words, op. (Pater, Pater dimitte illis quia nesciunt quid faciunt) — takes this fundamental step. This movement contains an early (and rather anomalous) example of a three-key exposition, a tonal innovation usually credited to Franz Schubert (Webster 1979, 3:61). ${ }^{18}$ The work begins in B-flat major; after modulating to the dominant, F major, the tonality moves to this key's parallel minor, then to its flatted submediant region (D-flat major) as the exposition concludes (see example 4). This passage sounds like a musical wrong turn rather than an expected tonal goal. Specifically, D-flat major is not perceived as the flatted mediant of the opening tonality; rather, it is to be understood as a third-related outgrowth of the subordinate key. Hepokoski and Darcy describe this tonal gambit as creating the effect of a subordinate theme "gone astray," with the concluding key acting as a (usually third-related) stand-in for the conventional

18 Longyear and Covington (198) discuss some classical (and pre-classical) antecedents of the three-key exposition, including certain of the works discussed above (including Haydn's Farewell Symphony). 

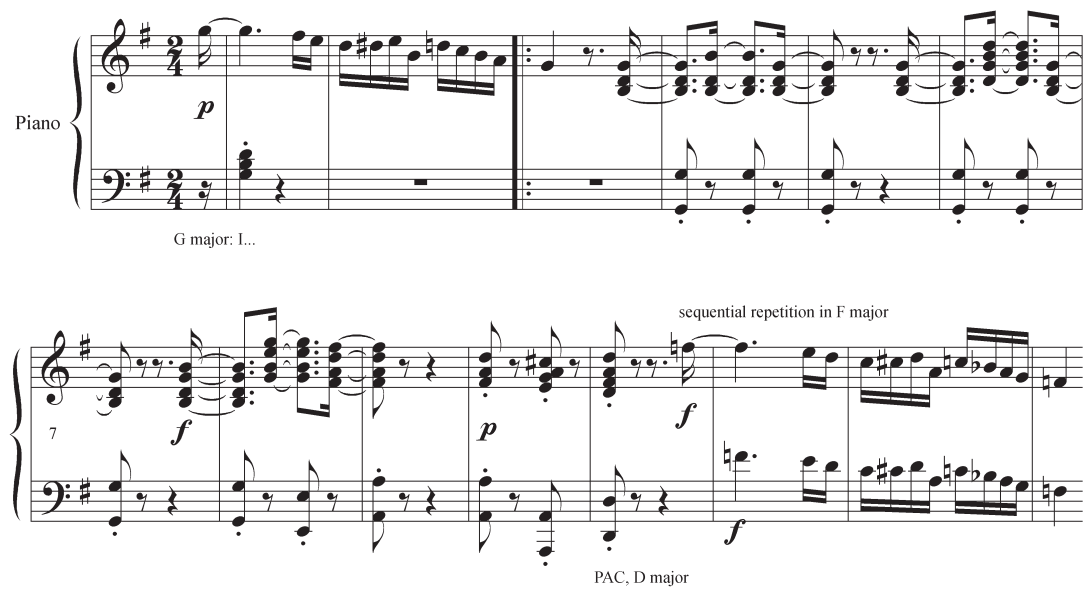

Example 5. Beethoven, Sonata in G major, op. 31, no. 1, first movement: main theme (mm. 1-14)

one. ${ }^{19}$ Thus, the tonic-dominant polarity typical of major-mode classical sonata expositions is still operative in such a movement, despite the tonally remote ending.

\section{III}

At the outset of the nineteenth century, Beethoven explored mediant relationships in his sonata-form works with great interest and not-inconsiderable frequency, using it occasionally in ways that Haydn and Mozart did not consider, as Rosen notes: "None of these examples [from K. 452 and Hob. XV: 28], although wonderfully dramatic, affect the basic tonal language: they are essentially coloristic, and make no attempt to set up the kind of polar opposition to the tonic reserved for the dominant. Beethoven, however, did often attempt to substitute third relationships for dominants, and to set up a direct polarized tension from a mediant to the tonic ... in these expositions, Beethoven prepares the mediants exactly as he would prepare a dominant [by preceding it with] the dominant of the mediant" $(1995,240)$.

Beethoven modulates to a chromatic mediant for the first time in the opening movement of his Sonata in G major, op. 31 , no. $1 .{ }^{20}$ Instead of using the conventional dominant key for the subordinate theme, Beethoven utilizes the

19 See Hepokoski and Darcy (2006, 178-79). The two examples they cite are the B-flat major slow movement of Mozart's Piano Concerto no. 14 in E-flat, K. 449, where the subordinate theme detours from the dominant key, F major, to A-flat major; and the E major slow movement of Beethoven's Piano Trio in G major, op. 1, no. 2, in which the subordinate theme moves from the dominant key, B major, to its lowered submediant, G major (thus recalling the trio's principal key).

20 Around the same time, Beethoven used a chromatic submediant in the exposition of his String Quintet in C major, op. 29 (1801), first movement, using a subordinate theme that vacillates between A major and A minor. Also, one of his early bagatelles-op. 33, no. 2-modulates from F major to $\mathrm{D}$ major $(\# \mathrm{VI})$ in the first part of its ABA design. Lockwood $(2003,395)$ argues that the bagatelle may predate op. 31, no. 1, despite its higher opus number. 

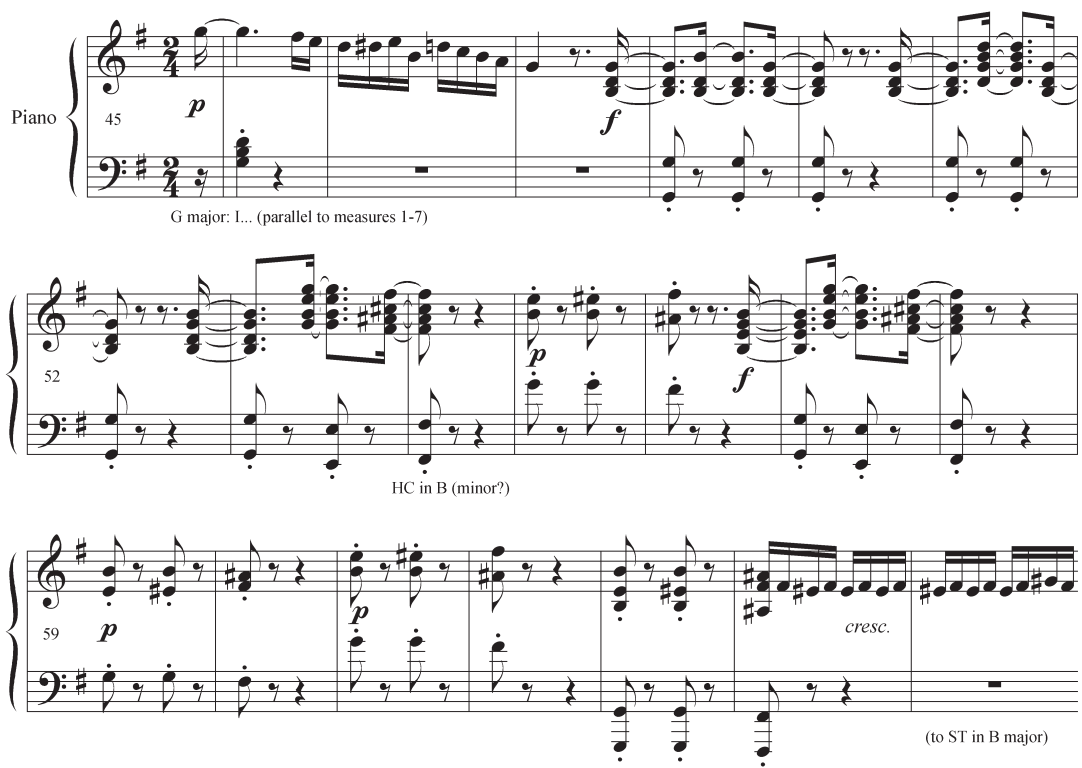

Example 6. Beethoven, Sonata in G major, op. 31, no. 1, first movement, mm. 45-65: end of transition, leading to beginning of mediant-related subordinate theme group

mediant major, B major (III\#). His use of this remote third-related key differs from Haydn's: unlike the former composer's Piano Trio in D major, where the appearance of this tonal relationship in the transition is merely a stopover on the way to the dominant, Beethoven's work sets up tonic and mediant in opposition to each other, as if he had transplanted the typical minor-mode third-related modulation into a major-mode sonata exposition. His decision to use a mediant-related subordinate key in this work is perhaps a consequence of the tonally rich manner in which he establishes the home key. As shown in example 5, the main theme's opening phrase begins on the tonic but quickly moves to the dominant, D major. Subsequently, the sequential repetition of this phrase, transposed down a whole step, emphasizes $\mathrm{F}$ major and $\mathrm{C}$ major. As three secondary keys (one of them, F major, relatively remote) had already appeared in the main theme, Beethoven seemingly saw the necessity of using a more distant subordinate key to provide an adequate tonal contrast with the opening material. Moreover, since Beethoven incorporates an emphatic (if fleeting) modulation to D major in $\mathrm{mm}$. 8-11 (albeit just an extended prolongation of the dominant at its initial appearance), the reuse of this key in the subordinate theme group, as would have been customary, might have struck Beethoven as being tonally unnecessary, even redundant.

Beethoven begins the surprising modulation to the mediant major in the transition (see example 6). This section begins by restating the opening measures note-for-note (mm. 46-52 are exactly parallel to mm. 1-7). At its first appearance, this segment had closed on the dominant, but when the parallel passage reaches this juncture, Beethoven leads instead to an F-sharp major triad 
(the dominant of the mediant) in m. 54. This chord repeats intermittently for twelve measures, as if to prepare the movement's unusual subordinate key (initially B major, subsequently B minor, the diatonic mediant) more convincingly.

Beethoven's use of third-related tonal juxtapositions in major-mode expositions continues with his Sonata in C major, op. 53, whose first movement comprises a refined reworking of the tonal plan from op. 31, no. 1 (Kamien 1992, 95; Rosen 1998, 396-99; 2002, 180-88; and Spitzer 1996, 109, among others). Both works begin with a descending step sequence, emphasizing the subtonic and subdominant tonal regions. In both works, Beethoven moves to the mediant major instead of the dominant in the subordinate theme group (m. 66 in op. 31, no.1; $\mathrm{m} .35$ in op. 53), and concludes the exposition in the more closely related mediant minor, though this latter key is less prominent in op. 53 than it had been in op. 31, no. 1, where it dominates the exposition's second half, until a retransition in $\mathrm{mm} .84-85$ restores the customary dominant for the exposition's repeat.

Though I have focused primarily on sonata expositions until now, it is interesting to note the similar way in which Beethoven tonally compensates in the recapitulations of op. 31, no. 1, and op. 53 for the chromatic mediant excursions in their respective expositions. In both movements, Beethoven balances mediant emphasis in the exposition with submediant emphasis in the recapitulation. This is a more intricate tonal plan than the norm in major-mode sonata-form movements, but it is based on the same linking of chords that share common tones. The move to the chromatic mediant elicits from Beethoven an equal and opposite (albeit brief) excursion to the chromatic submediant later in the work to reestablish tonal balance. ${ }^{21}$ This sensitivity to creating a sense of equilibrium in his large-scale harmonic relationships is evidence of the increasing sophistication of Beethoven's tonal sense as the nineteenth century began.

\section{IV}

With any formal or tonal innovation, it would not be surprising for a composer to explore new and bold techniques fairly exhaustively, discovering through multiple works the range of possibilities and their musical utility. However, once such a technique is perfected, it tends to be relegated to the role of one of many viable options. If we see the experiments of Beethoven's opp. 23-31 as the intensive working-out of the possibilities of formal mixture, then the opening movements of the Waldstein sonata, op. 53 and the Triple Concerto, op. 56 (both of which share op. 31, no. 1's I-III\# tonal plan in the exposition), and the concluding movement of the sonata in F minor (Appassionata), op. 57 (which, along with the opening movement of the Kreutzer sonata, op. 47, moves from tonic to dominant minor in its exposition) represent the first maturity of this procedure. Once Beethoven had reached this stage of satisfaction with exploring

21 Such tonal plans recall the traditional move to the subdominant in the recapitulation as a tonal balancing of the standard I-V motion in an eighteenth-century major-mode sonata exposition. Rosen (1998, 460-66), cites a number of examples from Beethoven, including his piano sonatas op. 22, 28 (Pastoral), and 81a (Das Lebewohl). 
wider-ranging tonal plans in his sonata expositions, he largely avoided the use of such devices for the remainder of his career, preferring, more often than not, to conform tonally to conventional high classical models. Only a small fraction of his sonata-form works written after op. 57 use formal mixture in their expositions: four minor-mode movements-the Coriolan Overture, opus 62, the sonatas op. 90, first movement, and op. 109, second movement, and his Cello Sonata, op. 102, no. 1, first movement-modulate to the dominant minor, ${ }^{22}$ and six major-mode movements (to be discussed below) modulate to third-related keys, five of them involving chromatic third relations, the anomaly being the diatonic third motion from E-flat major to $\mathrm{G}$ minor in the opening movement of his String Quartet in E-flat major, op. 127. There are a total of ten sonata expositions written after op. 57 in which Beethoven utilizes formal mixture. ${ }^{23}$

Among the relatively small subcategory of Beethoven's sonata-form works after op. 57 that explore chromatic third relations in their expositions, there are three striking late examples that comprise three of the four common chromatic third relationships in their respective expositions: the first movement of the Hammerklavier Sonata, op. 106, in B-flat major, whose subordinate theme is in G major (VI\#); the opening movement of Beethoven's string quartet, op. 130, also in B-flat major, which modulates to G-flat major (bVI) for the subordinate theme; and the finale of Beethoven's last quartet (op. 135, in F major), whose subordinate theme is in A major (III\#). ${ }^{24}$ We will consider each of these works in turn, exploring how Beethoven's employment of formal mixture in these respective expositions necessitates a complex tonal balancing later in the form.

In the first movement of op. 106, Beethoven duplicates the I-VI\# expositional tonal plan that he had employed in the opening movement of the Archduke Trio, op. 97, seven years prior. In the earlier work, Beethoven simply recapitulates the subordinate theme in the tonic; however, in op. 106 he reworks the tonal scheme significantly. Beethoven's introduction of the chromatic submediant region mimics how he had introduced III\# in the opening movements of op. 31, no. 1, and op. 53. Following a main theme reference in the transition in $\mathrm{m} .35$, Beethoven introduces an extended $\mathrm{D}$ pedal ( $\mathrm{V}$ of the submediant) in $\mathrm{m} .37$, at the formal juncture where $\mathrm{V}$ of the dominant (a C-major chord) would normally be expected (Rosen $[1995,241]$ describes such a device as a "standard procedure for establishing a dominant [that has been] diverted to the mediant"). This pedal could have led to the diatonic submediant region, G minor-the E-flat that appears in the bass as the transition concludes (m. 44)

22 As an alternative to formal mixture, or to the common i-III expositional plan in his minormode movements, Beethoven modulates to VI for the subordinate theme on two occasions (see Hepokoski and Darcy [2006, 119-20, 317]): his Sonata in B-flat major, op. 106 (Hammerklavier), second third movement, his Sonata in C minor, op. 111, first movement, and his String Quartet in A minor, op. 127 , first movement.

23 I am considering the Leonore Overtures no. 2 and 3, op. 72-both of which modulate from C major to E major-to be variants of the same work.

24 The one third-related key absent from this sample, flat iii, appears once in Beethoven, as a minor-mode stand-in for the expected mediant major in the Appassionata Sonata, op. 57, first movement. Other than this singular instance, Beethoven used this tonal relationship only as the standard diatonic move from minor to relative major, as noted in Rosen (1995, 240). 
maintains this possibility-but Beethoven instead modulates, through the use of formal mixture, to the more remote \#VI (G major) as the subordinate theme group begins.

This more remote tonal goal elicits from Beethoven an elaborate reworking of the recapitulation's tonal design to create an adequate musical counterpart to the exposition's I-VI\# large-scale motion. Unlike the previously examined op. 31, no. 1, and op. 53, in which Beethoven begins the subordinate theme group in the recapitulation with the chromatic submediant (\#VI) and subsequently "corrects" the tonality to the home key, here he makes wholesale tonal adjustments in the transition to permit the subordinate theme group to appear entirely in the tonic when it returns in the recapitulation. Beethoven approaches the subordinate theme with a surprising modulation to G-flat major (\#VII, enharmonically respelled) in mm. 249ff. In essence, this remote flat-side excursion to the diatonic submediant of the parallel minor effectively counterbalances the sharp-side excursion to $\mathrm{G}$ major (the parallel major of the diatonic submediant) from the exposition.

The G-flat major region ultimately becomes respelled as F-sharp major, which Beethoven treats as $\mathrm{V}$ of $\mathrm{B}$ minor, a remote tonality (best understood as the modally mixed Neapolitan key, or biib) in which he restates part of the main theme. Following a third-related move to a $G$ major triad, Beethoven then continues by circle of fifths beginning in $\mathrm{m}$. $271 \mathrm{until}$ he reaches the home key's dominant in m. 277 , over which the subordinate theme group finally begins in the home key of B-flat major. ${ }^{25}$ The two passages demonstrate the complex tonal and motivic processes by which Beethoven first introduces a striking tonal diversion, then resolves it through extensive reworking in the recapitulation.

In the opening movement of op. 130, Beethoven reaches the subordinate theme's remote tonality through a chromatic slither. At first, the transition feints toward the dominant of the home key in mm. 40-44, finally arriving on an F major triad as a goal. At this point, one might still think that the exposition will modulate to the customary dominant tonality after all. Instead, Beethoven provides ascending chromatic filler material, in unison, for the four instruments, leading ultimately to a unison D-flat. ${ }^{26}$ Once Beethoven establishes D-flat as a dominant in $\mathrm{m} .53$, a descending figure in the cello leads downward by fifth, after which the lyrical subordinate theme begins in the flatted submediant, G-flat major in $\mathrm{m} .55$.

As in op. 106, the ramifications of the exposition's third-related tonal plan reach far beyond that particular segment of the work. First of all, as Rosen has noted, Beethoven balances the use of the flatted submediant region (G-flat major) in the exposition by emphasizing the mediant major (D major, or \#III) in the development, thus emphasizing the pair of remote keys that lie a major

25 It could also be argued that the prominence of B minor in the recapitulation's subordinate theme group might refer back to the extended B-major segment that concludes the development (measures 213ff.).

${ }^{26}$ Kerman $(1966,209)$ remarks, "Nothing so far ... has prepared us for so mechanistic a move to [this pitch]." Compare the discussion of this passage in Kinderman $(1995,299 f f)$. 
third on either side of the movement's original tonality (Rosen 1995, 245-46). Second, the exposition's G-flat major tonal goal elicits a move to the flatted mediant (D-flat major) in the recapitulation's parallel passage, prepared, like the earlier passage, with a dominant pedal in the new key in $\mathrm{mm}$. 154-61. This balancing of bVI with bIII is reminiscent of Beethoven's III\#-VI\# tonal parallelism found in the opening movements of op. 31, no. 1, and op. 53. As the subordinate theme ensues, Beethoven moves up by third to an F major chord, leading to a half cadence in B-flat major, following which the remainder of the subordinate theme recapitulates in the home key. ${ }^{27}$

Finally, let us consider the finale of Beethoven's string quartet in F major, op. 135. Here, the use of formal mixture helps to counterbalance the work's relatively conventional formal design. Following a slow introduction in F minor, in which Beethoven states the movement's characteristic "Muß es sein" ("must it be?") motive (G-E-A flat), the exposition begins in F major with a free inversion of this gesture (A-C-G, the "Es muß sein"- "it must be"-motive) as the main theme's incipit in mm.14-16. Beethoven balances the introduction's flat-side excursion by moving to the sharp side of $\mathrm{F}$ major as the exposition continues. After an E pedal and three measures of monophonic filler, the subordinate theme begins in A major (III\#) and remains there through the exposition's conclusion (see example 7).

Following the tonally remote goal of the movement's first half, a modal shift brings the development closer to the home key: its first gesture (m. 82) is the "Es muß sein" motive, stated in A minor. This passage leads to an extended reworking of opening material in the dominant key, $\mathrm{C}$ major, beginning in $\mathrm{m}$. 87. However, Beethoven's fixation with sharp-side remote keys resumes, as he soon modulates to $\mathrm{D}$ major $(\# \mathrm{VI})$ in $\mathrm{m}$. 10, subsequently restating subordinate theme material (see example 8).

D major then returns early in the recapitulation, "as though to balance A major, which was the second key of the exposition," as Kerman $(1966,365)$ tellingly remarks (see example 9). ${ }^{28}$ The similarity of tonal strategy to op. 31 , no. 1 , and op. 53 is obvious, but here, VI\# not only tonally balances the exposition's III\#, but also recalls the pairing of $\mathrm{D}$ major and subordinate theme material in the development. Also, much like the excursion to B minor in the recapitulation of op. 106, this early introduction of a sharp-side remote key allows Beethoven both the opportunity to recall a different sharp-side tonal diversion in the exposition, and the time and space to reestablish the tonic key for the subordinate theme's closing phrases and coda.

27 Kinderman (2006, 296-300) notes the "whimsy and unpredictability" of this movement's thematic and tonal shape.

28 Kerman $(1966,365)$. 

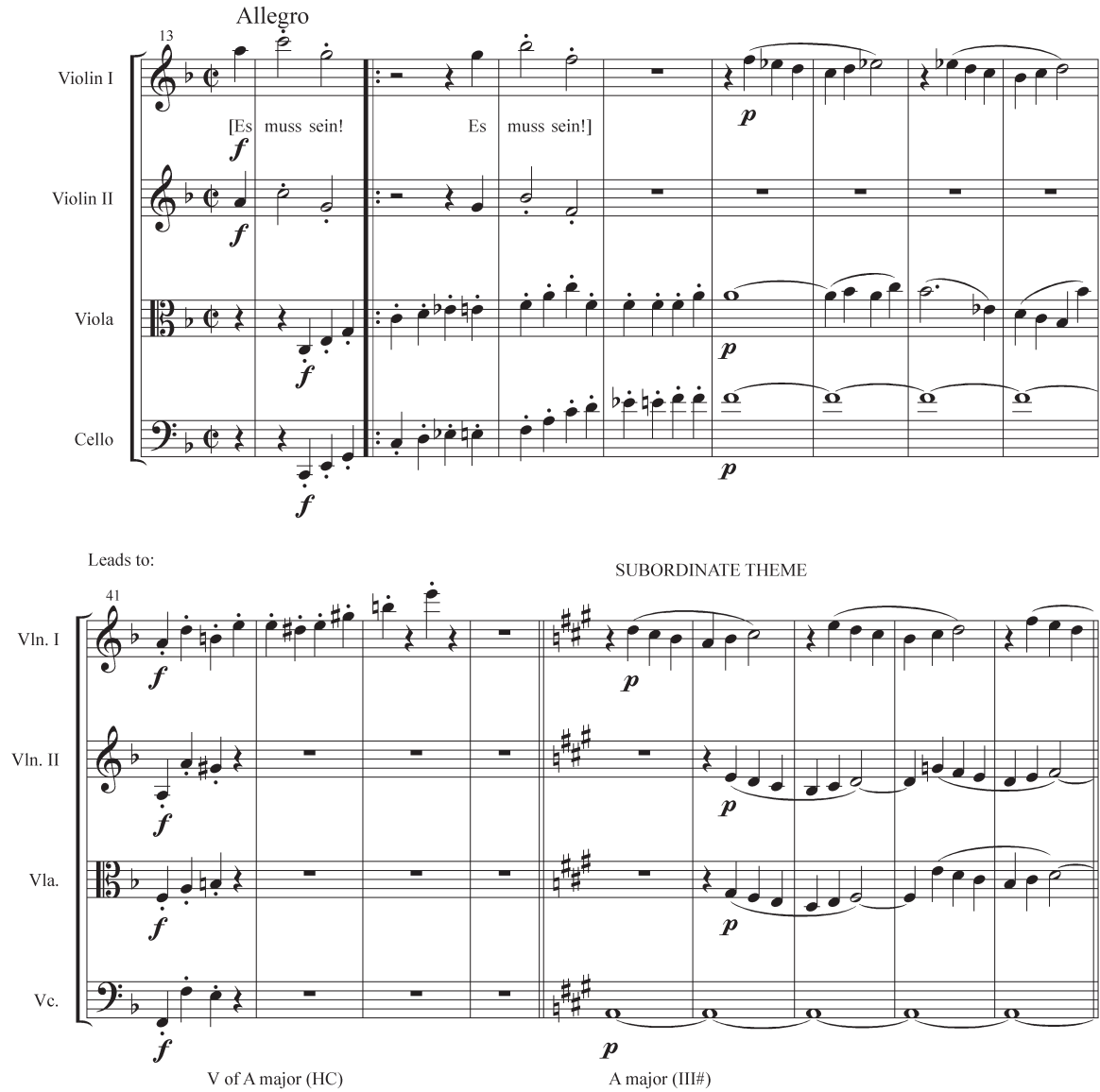

Example 7. Beethoven, String Quartet in F major, op. 135, Finale: beginning of main theme (mm. 13-20) and transition to subordinate theme (mm. 41-49)

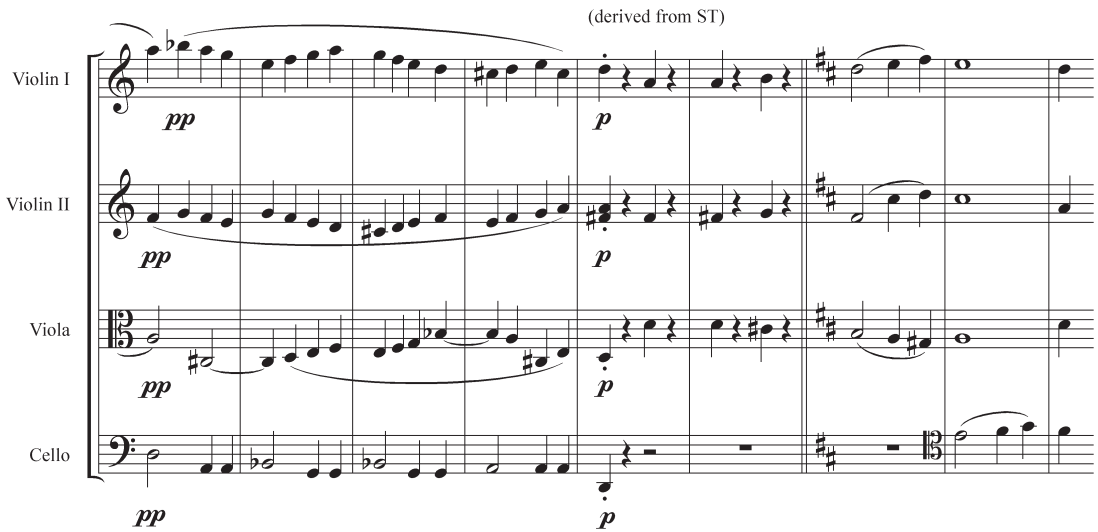

Example 8. Beethoven, String Quartet in F major, op. 135, Finale, mm. 106-14: modulation to $\mathrm{D}$ major $(\# \mathrm{VI})$ 


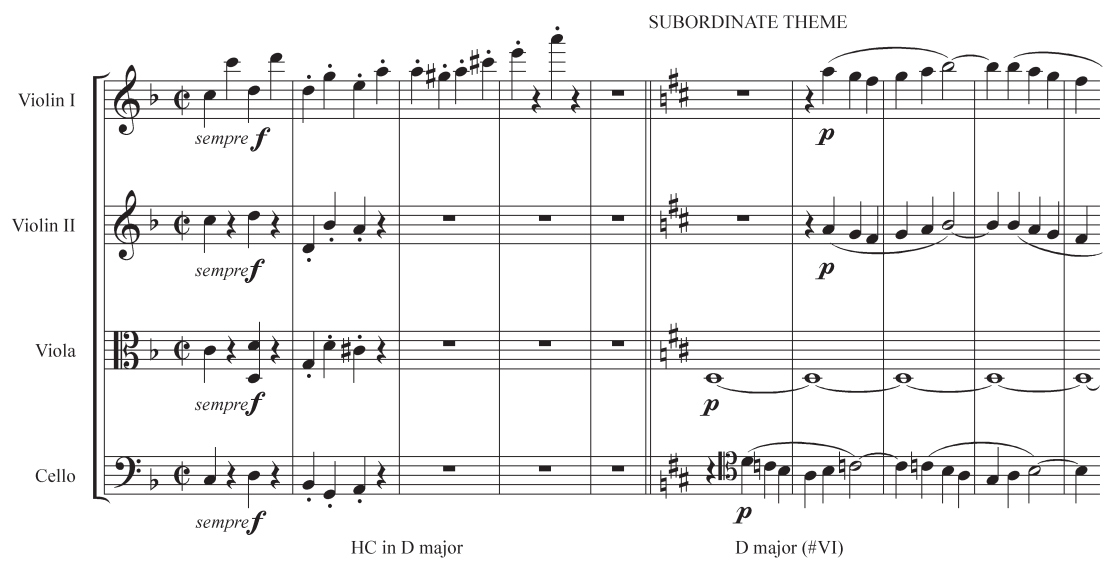

Example 9. Beethoven, String Quartet in F major, op. 135, Finale, mm. 194-203: transition to subordinate theme

\section{ConCLUSION}

The tonal plans of Beethoven's experimental sonata expositions from opp. 2331, building on the isolated experiments of his predecessors such as Haydn, Mozart, Domenico Cimarosa, and C. P. E. Bach, led him to a new, more flexible conception of large-scale tonal design, and a sophisticated, delicate balancing of disparate remote keys within a sonata-form movement. Juxtaposing majormode and minor-mode sonata-exposition procedures, thereby using modal mixture at a deeper structural level than composers had attempted heretofore, allowed Beethoven to explore new and wider-ranging tonal devices at an earlier point in a sonata-form movement, thus becoming a means by which increased chromaticism at the level of detail could be projected more deeply into the formal-thematic structure of a composition. This new and more extensive conception of large-scale formal and tonal design remains one of his most striking accomplishments. 
Appendix: Beethoven's Sonata-Form Expositions That Use Formal Mixture

\begin{tabular}{|c|c|c|}
\hline Work & Movement & Tonal Plan of Exposition \\
\hline Piano Quartet, WoO 36, no. 1 & 2 & e-flat $\rightarrow$ b-flat \\
\hline Piano Sonata, op. 2, no. 1 & 4 & $f \rightarrow c$ \\
\hline Violin Sonata, op. 23 & 1 & $a \rightarrow e$ \\
\hline Piano Sonata, op. 27, no. 2 & 3 & c-sharp $\rightarrow$ g-sharp \\
\hline String Quintet, op. 29 & 1 & $C \rightarrow A \rightarrow a$ \\
\hline Piano Sonata, op. 31 , no. 1 & 1 & $\mathrm{G} \rightarrow \mathrm{B} \rightarrow \mathrm{b}$ \\
\hline Piano Sonata, op. 31, no. 2 (Tempest) & 1 & $d \rightarrow a$ \\
\hline Piano Sonata, op. 31 , no. 2 & 3 & $d \rightarrow a$ \\
\hline Violin Sonata, op. 47 (Kreutzer) & 1 & $a \rightarrow e$ \\
\hline Piano Sonata, op. 53 (Waldstein) & 1 & $\mathrm{C} \rightarrow \mathrm{E} \rightarrow \mathrm{e}$ \\
\hline Triple Concerto, op. 56 & 1 & $C \rightarrow A$ \\
\hline Piano Sonata, op. 57 & 3 & $f \rightarrow c$ \\
\hline Coriolan Overture, op. 62 & - & $c \rightarrow(E-f l a t) \rightarrow g$ \\
\hline Leonore Overture no. 2, op. 72 & - & $C \rightarrow E$ \\
\hline Leonore Overture no. 3, op. 72 & - & $C \rightarrow E$ \\
\hline Piano Sonata, op. 90 & 1 & $e \rightarrow b$ \\
\hline Piano Trio, op. (Archduke) & 1 & B-flat $\rightarrow G$ \\
\hline Cello Sonata, op. 102 , no. 1 & 1 & $a \rightarrow e$ \\
\hline Piano Sonata, op. 106 (Hammerklavier) & 1 & B-flat $\rightarrow G$ \\
\hline Piano Sonata, op. 109 & 2 & $e \rightarrow b$ \\
\hline String Quartet, op. 127 & 1 & E-flat $\rightarrow g$ \\
\hline String Quartet, op. 130 & 1 & B-flat $\rightarrow$ G-flat \\
\hline String Quartet, op. 135 & 4 & $\mathrm{~F} \rightarrow \mathrm{A}$ \\
\hline
\end{tabular}

\section{Works Cited}

Caplin, William E. 1998. Classical Form: A Theory of Formal Functions for the Instrumental Music of Haydn, Mozart and Beethoven. New York: Oxford University Press.

Geiringer, Karl, and Irene Geiringer. 1982. Haydn: A Creative Life in Music. Berkeley: University of California Press.

Haimo, Ethan. 2011. "Haydn's Debt to Cimarosa." In Haydn and His Contemporaries, ed. Sterling Murray, 39-55. Ann Arbor, MI: Steglein Publishing. Hepokoski, James, and Warren Darcy. 2006. Elements of Sonata Theory: Norms, Types and Deformations in the Late-Eighteenth-Century Sonata. New York: Oxford University Press.

Kamien, Roger. 1992. "Subtle Enharmonic Connections, Modal Mixture and Tonal Plan in the First Movement of Beethoven's Piano Sonata in C Major, Opus 53 ('Waldstein')," Beethoven Forum 1:93-110.

Kerman, Joseph. 1966. Beethoven's String Quartets. New York: Norton. -1994. "Beethoven's Minority." In Write All These Down: Essays on Music, 217-37. Berkeley: University of California Press. 
Kinderman, William. 1995. Beethoven. Oxford: Oxford University Press.

—_ 2006. "Beethoven's Last Quartets: Threshold to a Fourth Creative Period?" In The String Quartets of Beethoven, 279-322. Urbana: University of Illinois Press.

Larsen, Jens Peter. 1988. "Sonata Form Problems." In Handel, Haydn and the Viennese Classical Style, trans. Ulrich Krämer, 269-79. Ann Arbor: University of Michigan Research Press.

Lockwood, Lewis. 2003. Beethoven: The Music and the Life. New York: Norton. Longyear, Rey, and Kate Covington. 1988. "Sources of the Three-Key Exposition." Journal of Musicology 6 (4): 448-70.

Miller, Malcolm. 2004. "Beethoven's Early Piano Quartets WoO 36 and the Seeds of Genius: An Historical Fantasy and Analysis." Arietta: Journal of the Beethoven Piano Society Piano of Europe 4:18-24.

Robbins Landon, H. C. 1978. Haydn: Chronicle and Works. Vol. 2. Bloomington: Indiana University Press.

Robbins Landon, H. C., and David Wyn Jones. 1988. Haydn: His Life and Works. Bloomington: Indiana University Press.

Rosen, Charles. 1988. Sonata Forms. Rev. ed. New York: Norton. . 1995. The Romantic Generation. Cambridge, MA: Harvard University Press.

-1998. The Classical Style. Exp. ed. New York: Norton.

-2002. Beethoven's Piano Sonatas: A Short Companion. New Haven, CT: Yale University Press.

Spitzer, Michael. 1996. "The Significance of Recapitulation in Beethoven's Waldstein Sonata." Beethoven Forum 5:103-17.

Webster, James. 1978-79. "Schubert's Sonata Form and Brahms's First Maturity." 19th Century Music 2:18-35; 3:52-71.

- 1991. Haydn's "Farewell" Symphony and the Idea of Classical Style: Through-Composition and Cyclic Integration in His Instrumental Music. Cambridge, UK: Cambridge University Press, 1991.

_.2001. "Sonata Form." In New Grove Dictionary of Music and Musicians. 2nd ed. Ed. Stanley Sadie and John Tyrrell. London: Macmillan.

\footnotetext{
ABSTRACT

Modal mixture is defined as a local colouration of a diatonic progression by borrowing tones or chords from the parallel major or minor tonality. In his efforts to expand tonal resources, Beethoven took this technique further: he borrowed large-scale tonal processes from a composition's parallel tonality, a technique that I term formal mixture. After tracing its origin to certain works by J. S. Bach, C. P. E Bach, Domenico Scarlatti, and Joseph Haydn, I demonstrate how Beethoven built upon his predecessors' use of the technique throughout his career, thereby expanding and diversifying the tonal resources of late classical era sonata forms.
} 


\section{RÉSUMÉ}

La modulation diatonique se définit comme la coloration locale d'une progression diatonique par l'emprunt de tons ou d'accords à la tonalité majeure ou mineure homonyme. Dans ses efforts visant l'élargissement des ressources tonales, Beethoven a fait avancer cette technique : il a emprunté des processus sonores de grande échelle de la tonalité homonyme d'une composition, technique que je qualifie de modulation formelle. Après en avoir retracé les origines à certaines œuvres de Johann Sebastian Bach, Carl Philipp Emanuel Bach, Domenico Scarlatti et Joseph Haydn, je montre comment tout au long de sa carrière Beethoven s'est appuyé sur l'emploi de cette technique par ses prédécesseurs, élargissant et diversifiant ainsi les ressources tonales des structures sonate de la fin de l'ère classique. 